Br. phycol. J. 23: 251-258

1 September 1988

\title{
Studies of Marine Epiphytic Algae, Calvi, Corsica. I. Determination of Minimal Sampling Areas for Microscopic Algal Epiphytes
}

\author{
By A. Wilmotte, A. Goffart and V. Demoulin \\ Département de Botanique, B.22, Université de Liège (Sart Tilman), \\ B-4000 Liège I, Belgium
}

\begin{abstract}
Minimal sampling areas have been determined for marine Bangiophyceae and Cyanophyceae epiphytic on Cladophora prolifera and Halopteris scoparia in Calvi, Corsica. This was done by observing the stabilization of species/area curves and of qualitative and quantitative similarity coefficients between samples of increasing size. For Cyanophyceae (studied only on Cladophora) the minimal sampling area is in the order of $15-38 \mathrm{~mm}^{2}$, depending on the method used. The sampling area is smaller when the quantitative similarity coefficient is used, apparently because of the rather homogeneous distribution of a few abundant taxa. For the same reason the quantitative similarity coefficient stabilizes at a high value (75\%). For Bangiophyceae on Cladophora, the area is of the order of $7-10 \mathrm{~mm}^{2}$, but a larger area is necessary for the quantitative than for the qualitative coefficient. The stabilized value of the quantitative coefficient is relatively low $(66 \%)$, despite the fact that the qualitative coefficient reaches $94 \%$. On Halopteris, by counting only on medium sized ramifications (about $100 \mu \mathrm{m}$ in diameter), one can use a sampling area as low as $0.1-0.5 \mathrm{~mm}^{2}$ and obtain a qualitative similarity coefficient of $100 \%$ and a quantitative one of $80 \%$. This study demonstrates that techniques used for macrophytic vegetation can be applied with success to microscopic epiphytes.
\end{abstract}

Seaweeds are often covered by an abundant growth of smaller algae. Although the larger epiphytes are usually included in vegetation studies, together with their basiphytes, the microscopic ones have been relatively little studied (Round, 1981: ch. 6). These, however, have a significant ecological role, e.g. the nitrogen fixing blue-green algae. A prerequisite of any investigation of such communities is the determination of the minimal sample size necessary to characterize such populations. This is a critical ecological problem and the object of numerous publications concerning terrestrial biota (Gounot, 1969; Kershaw, 1973) and seaweed communities (Boudouresque, 1971, 1974; Nedelec, 1979; Coppejans, 1980). We have approached this problem for Cyanophyceae and Bangiophyceae, two groups that are especially important in the early colonization of the youngest parts of growing seaweeds. In addition, these groups show a major development in nutrient enriched environments, such as harbours, and are thus important in the study of the algal vegetation of disturbed habitats (Golubić, 1970; Munda, 1974; Belsher \& Boudouresque, 1976; Whitton \& Potts, 1982; Marcot-Coqueugniot, Boudouresque \& Knoepffler, 1984).

\section{MATERIALS AND METHODS}

The basiphytes studied were the green alga Cladophora prolifera (Roth) Kütz., which is a pollution-tolerant species abundant in harbours (Hoek, 1963; Schramm \& Booth, 1981) and a substrate transparent enough for an easy study of microscopic epiphytes, and the brown alga Halopteris scoparia (L.) Sauv. [Stypocaulon s. (L.) Kütz.] a widespread species in the Calvi area (Corsica) where we are conducting studies on algal vegetation. Collecting was done by SCUBA diving and the material preserved in $5 \%$ formaldehyde in sea-water. Both Bangiophyceae and Cyanophyceae were studied on C. prolifera 
collected in July 1981 at a depth of $1.5 \mathrm{~m}$ in the harbour of STARESO (field station of the University of Liège on Punta Revellata near Calvi). Cyanophyceae were also studied on C. prolifera in the ferry harbour of Calvi (March 1982, depth $5 \mathrm{~m}$ ) and Bangiophyceae on $H$. scoparia collected outside the harbours (NE of Calvi citadelle, September 1981, depth $5 \mathrm{~m}$ ).

For the determination of the minimal sampling area we have used three approaches: the species/area curve and techniques using a qualitative and a quantitative similarity coefficient. The species/area curve presents the relationship between the number of species encountered and the size of the sample. With the similarity coefficients, one observes the stabilization of the similarity coefficient calculated between samples of equal size as this size increases. In this study, the value given is the mean of three coefficients calculated by comparing three samples. We have utilized two widely used coefficients, the qualitative one of Sørensen (1948) and the quantitative one attributed to Kulczynski by Boudouresque (1971) and to Czekanowski by Goodall (1973).

The Sørensen coefficient is defined as

$$
S=\frac{2 C_{p q}}{\mathrm{n}_{p}+\mathrm{n}_{q}} \times 100,
$$

where $C_{p q}$ is the number of taxa common to samples $p$ and $q, n_{p}$ and $n_{q}$ the number of taxa present respectively in samples $p$ and $q$.

The Czekanowski coefficient is

$$
S=\frac{2 \sum_{i=1}^{n} \inf \left(R_{i p}, R_{i q}\right)}{\sum_{i=1}^{n} R_{i p}+\sum_{i=1}^{n} R_{i q}} \times 100,
$$

where for $n$ taxa, $R_{i p}$ and $R_{i q}$ are respectively the number of individuals of taxon $i$ in sample $p$ and $q$, and $\inf \left(R_{i p}, R_{i q}\right)$ is the lowest of the two values $R_{i p}$ and $R_{i q}$.

The approaches employed in this study require identification of taxa (species) as well as individuals for the purposes of quantification of data. The use of these concepts for microorganisms in general, and for Cyanophyceae in particular, is not standardized. For the purposes of this study we have introduced our own definitions.

The species concept for Bangiophyceae (six taxa) is close to that used by Garbary, Hansen \& Scagel (1980). For the Cyanophyceae (13 taxa) the species concept employed (reported in the following paper of this series), is somewhat broader than that of Geitler (1930-1932). We suspect that the concept used here for Cyanophyceae is in some cases too broad, but it has been devised for field observations in order to be able to assign every individual to a particular category.
Defining an individual for the Bangiophyceae was relatively easy, as all the species observed were multicellular, with cells at least $5 \mu \mathrm{m}$ in diameter. Counting could thus be performed using a $40 \times$ objective.

For Cyanophyceae the following conventions have been adopted for defining individuals: each filament is counted as one individual for filamentous Cyanophyceae, and each colony for the non-filamentous ones. Two colonies have been recorded as separate individuals as soon as they are separated by a distance equal to two cell diameters. Counting was performed using a $100 \times$ oil immersion objective of high quality, which is necessary given the small size of some Cyanophyceae.

\section{RESULTS}

\section{Choice of sampling units on the basiphyte Cladophora}

The study of microscopic epiphytes has to face the following two problems: (1) Most shoots of a basiphyte offer a surface too small to be representative of the total epiphyte population in a stand of that basiphyte. The epiphytes must therefore be counted on several randomly selected shoots from the basiphyte population. The minimal sampling area is thus constituted by addition of several such shoots. (2) The density of the epiphytic cover is a function of the age of the shoot. Consequently, the samples will never be perfectly homogeneous.

Cyanophyceae and even more so the Bangiophyceae are fast growing early colonizers of shoot apices. On older parts, they however have to compete with larger algae, especially encrusting Corallinaceae. This relationship was evident in the millimetre-by-millimetre count of Bangiophyceae along the first centimetre of $20 \mathrm{C}$. prolifera shoots (Stareso, 1.5 m, July 1981, Table I).

For the Bangiophyceae, the sampling unit on Cladophora has thus been defined as the upper surface of the first $6 \mathrm{~mm}$ (starting from the apex) of an average shoot which is flattened under the cover-slip. Such an average shoot is about $200 \mu \mathrm{m}$ wide at $3 \mathrm{~mm}$ from the apex, and the sampling unit is thus in the order of $1.2 \mathrm{~mm}^{2}$.

For Cyanophyceae, the situation is more complex for if they already settle on the apex 


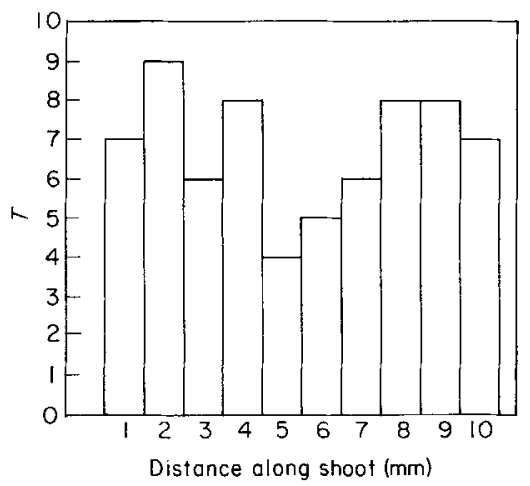

FIG. 1. Number of "taxa" $(T)$ of Cyanophyceae encountered millimetre-by-millimetre when the countings performed along the first centimetre (starting from the apex) of 45 Cladophora prolifera shoots of average size $(200 \mu \mathrm{m}$ at $3 \mathrm{~mm}$ from the apex) are pooled (Calvi, STARESO, depth $1.5 \mathrm{~m}$, July 1981).

of growing shoots they remain present on the whole plant. Along a shoot, variations in their density do occur, apparently in relation to competition with Corallinaceae and other larger epiphytes. Figures 1 and 2 show the number of taxa and of individuals that have been found millimetre-by-millimetre when the countings performed along the first centimetre of 45 average $C$. prolifera shoots are pooled. The minimum near the fifth millimetre is in the zone of maximal development of encrusting Corallinaceae. Further down, more space is available among aging Corallinaceae and the blue-

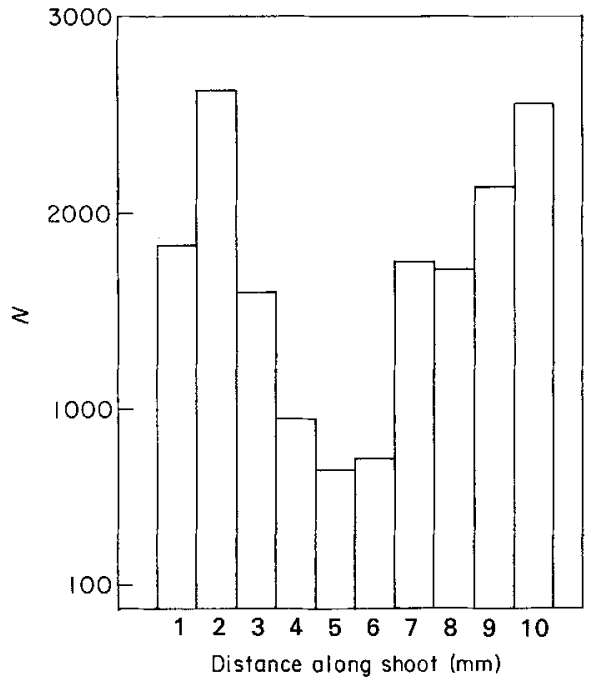

FIG. 2. Number of "individuals" $(N)$ of Cyanophyceae encountered millimetre-by-millimetre when the countings performed along the first centimetre (starting from the apex) at 45 Cladophora prolifera shoots of average size $(200 \mu \mathrm{m}$ at $3 \mathrm{~mm}$ from the apex) are pooled (Calvi, STARESO, depth $1.5 \mathrm{~m}$, July 1981).

green algae thrive again. One should note their great abundance, the average number of individuals on $1 \mathrm{~mm}$ of shoot varying from 16 to 59 .

Unlike the Bangiophyceae, therefore one cannot here select an area where the population is best developed. Thus we have arbitrarily chosen the first centimetre from the apex of the upper face of an average

TABLE I. Distribution of Bangiophyceae on a Cladophora prolifera shoot: number of individuals millimetre-bymillimetre (cumulative count for 20 shoots of average size, that is $200 \mu \mathrm{m}$ wide at $3 \mathrm{~mm}$ from the apex)

\begin{tabular}{|c|c|c|c|c|c|c|c|c|c|c|c|}
\hline \multirow[b]{2}{*}{ Species } & \multicolumn{10}{|c|}{ Distance from apex (mm) } & \multirow{2}{*}{$\begin{array}{c}\text { Total } \\
\text { for each } \\
\text { taxon }\end{array}$} \\
\hline & 1 & 2 & 3 & 4 & 5 & 6 & 7 & 8 & 9 & 10 & \\
\hline $\begin{array}{l}\text { Goniotrichum alsidii (Zanard.) } \\
\text { Howe }\end{array}$ & 11 & 7 & 1 & 1 & 1 & 0 & 1 & 0 & 0 & 0 & 22 \\
\hline $\begin{array}{l}\text { Goniotrichum cornu-cervi (Reinsch) } \\
\text { Hauck }\end{array}$ & 1 & 0 & 2 & 0 & 1 & 3 & 0 & 0 & 0 & 0 & 7 \\
\hline $\begin{array}{l}\text { Erythrotrichia carnea (Dillw.) J. } \\
\mathrm{Ag} .\end{array}$ & 3 & 3 & 0 & 0 & 0 & 0 & 0 & 0 & 0 & 0 & 6 \\
\hline $\begin{array}{l}\text { Erythrocladia irregularis Rosenv. } \\
\text { form with bifid marginal cells }\end{array}$ & 5 & 4 & 3 & 0 & 0 & 1 & 1 & 0 & 0 & 0 & 14 \\
\hline $\begin{array}{l}\text { E. irregularis Rosenv. form with } \\
\text { non-bifid marginal cells }\end{array}$ & 3 & 5 & 9 & 4 & 1 & 5 & 1 & 0 & 1 & 0 & 29 \\
\hline $\begin{array}{l}\text { Chroodactylon ornatum (C. Ag.) } \\
\text { Basson }\end{array}$ & 2 & 0 & 0 & 0 & 0 & 0 & 0 & 0 & 0 & 0 & 2 \\
\hline Total of Bangiophyceae & 25 & 19 & 15 & 5 & 3 & 9 & 3 & 0 & 1 & 0 & 80 \\
\hline
\end{tabular}




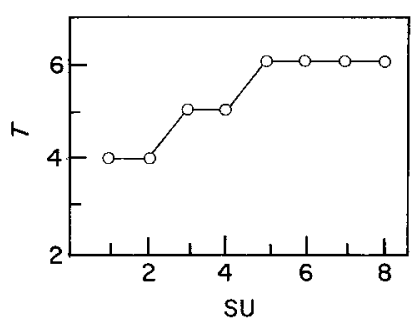

FIG. 3. Number of taxa of Bangiophyceae $(T)$ in relation to the number of sampling units (SU) of Cladophora prolifera (Calvi, STARESO, depth $1.5 \mathrm{~m}$, July 1981).

shoot $(200 \mu \mathrm{m}$ thick at $3 \mathrm{~mm}$ from the apex, $250 \mu \mathrm{m}$ at $5 \mathrm{~mm}$, when flattened under the cover-slips), which is easier to observe than thicker parts. Furthermore all the species can be present from the fourth millimetre onward. In this way areas more-or-less covered by Cyanophyceae are included and this first centrimetre (area about $2.5 \mathrm{~mm}^{2}$ ) might thus be representative of a large part of the total epiphytic cover.

\section{Minimal sampling areas on Cladophora}

This study was performed with material from the STARESO harbour, July 1981. Another species/area curve for Cyanophyceae was determined in a different place and a different season (Ferry harbour in March 1982).

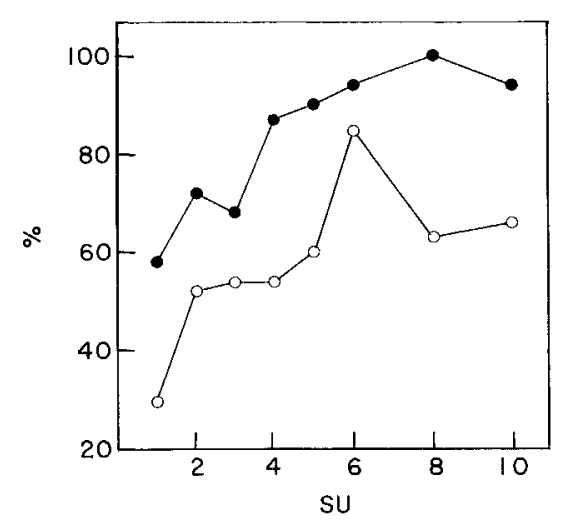

FIG. 4. Qualitative (O) and quantitative (O) similarity coefficients in comparisons involving a growing number of added sampling units (SU), for Bangiophyceae on Cladophora prolifera (Calvi, STARESO, depth $1.5 \mathrm{~m}$, July, 1981).

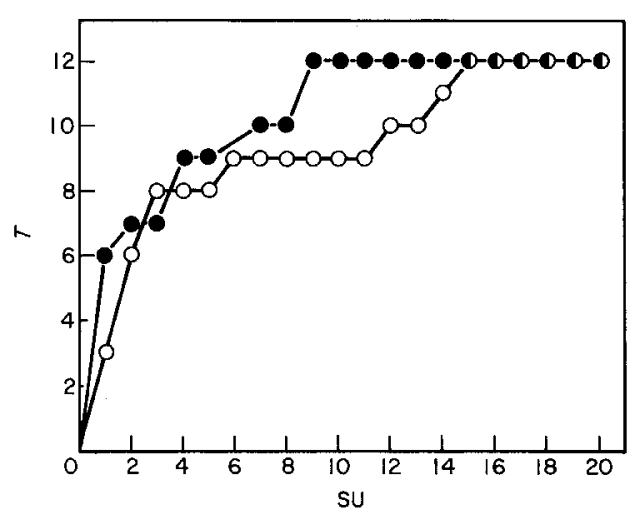

FIG. 5. Number of taxa of Cyanophyceae $(T)$ in relation to the number of sampling units (SU) of Cladophora prolifera of two localities: Calvi STARESO, depth $1.5 \mathrm{~m}$, July 1981 (O); Calvi, Ferry harbour, depth $5 \mathrm{~m}$, March 1982 (O).

The species/area curve for Bangiophyceae (Fig. 3) shows that all six taxa are met with five sampling units (each the first $6 \mathrm{~mm}$ of an average shoot, area about $1.2 \mathrm{~mm}^{2}$ ). Figure 4 shows the change of the mean of three determinations of the similarity coefficients when groups from one to 10 sampling units are compared to another group containing the same number of sampling units. Those curves would suggest the choice of a minimal sampling area of six sampling units for a qualitative comparison and eight units for a quantitative one.

The species/area curve for Cyanophyceae in STARESO shows a stabilization with 15 sampling units (each the first centimetre of an average shoot, area about $2.5 \mathrm{~mm}^{2}$ ). In the Ferry harbour, stabilization was already reached with nine units (Fig. 5). In both

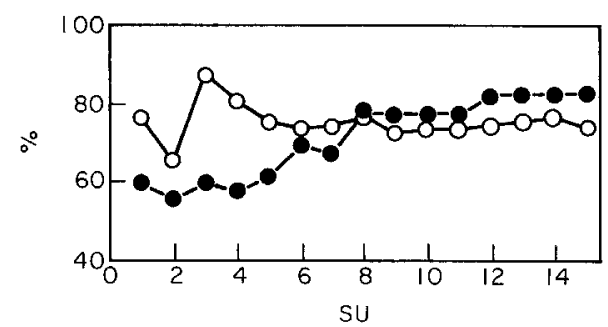

FIG. 6. Qualitative (O) and quantitative (O) similarity coefficients in comparisons involving a growing number of added sampling units (SU) for Cyanophyceae on Cladophora prolifera (Calvi, STARESO, depth $1.5 \mathrm{~m}$, July 1981). 


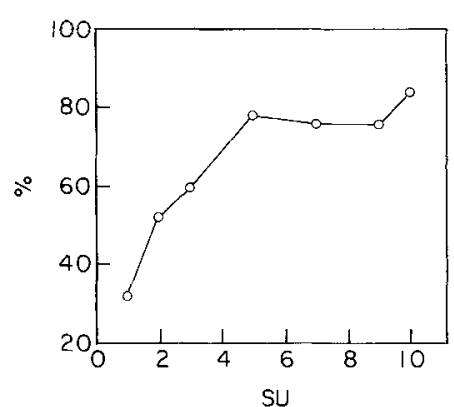

Fig. 7. Quantitative similarity coefficient in comparisons involving a growing number of added sampling units (SU), for Bangiophyceae on Halopteris scoparia (Calvi, Citadelle, depth $5 \mathrm{~m}$, Sept. 1981).

cases the final number of taxa was the same (12, 11 of which occurred in both harbours). When the qualitative similarity coefficient of Sørensen was used, a stabilization at $81 \%$ similarity was reached with a sampling area of 12 units. With the quantitative similarity coefficient of Czekanowski, a stabilization at $75 \%$ was reached with an area of six units (Fig. 6).

The rather high similarity values obtained indicate a more homogeneous population of Cyanophyceae than of Bangiophyceae on the same substratum.

\section{Bangiophyceae on Halopteris}

Halopteris scoparia is a brown seaweed with apical growth and dense irregularly pinnate ramification. Study of epiphytes is not as easy on this basiphyte as on $C$. prolifera and it was thus not used for the Cyanophyceae which are the most difficult to observe. Its broad distribution in the Calvi area, however, justifies its use to study the distribution of Bangiophyceae in various habitats. Bangiophyceae were especially abundant on the apex of secondary ramifications: about $30 \mathrm{~mm}^{-2}$, vs. $3 \mathrm{~mm}^{-2}$ on a primary ramification where the maximum, $16 \mathrm{~mm}^{-2}$, was met $3 \mathrm{~mm}$ from the apex. Those ramifications with high density of Bangiophyceae had a diameter of approximately $100 \mu \mathrm{m}$ and counting was limited to the first millimetre for they seldom are longer.
If the density of Bangiophyceae on such ramifications is high, the diversity, however, is low. In the material studied (a similar situation was observed in other locations), only two species are present which can be met with two sampling units. Species/area curve or qualitative similarity coefficient techniques are thus of little relevance. To study the homogeneity of the distribution of those two species, the quantitative coefficient of Czekanowski is however interesting. Figure 7 shows that it stabilizes at $80 \%$ similarity with groupings of five samples. This represents a much smaller minimal sampling area (of the order of $0.5 \mathrm{~mm}^{2}$ ) than on Cladophora (of the order of $9.6 \mathrm{~mm}^{2}$ ). On the latter, covering of Bangiophyceae was sparse (seldom more than $6 \mathrm{~mm}^{-2}$ ) but more diverse (all the taxa can be present in one sample), as has been ascertained by comparing the two basiphytes in localities where they grow together.

\section{DISCUSSION}

Table II summarizes our data with the sampling units transformed into their approximate surface equivalents. The apparent conclusion is that the communities with a higher taxonomic diversity, e.g. those on Cladophora, especially with respect to the Cyanophycean assemblage, require a higher minimal sampling unit to ensure that all taxa are met. However, when one wants to describe the vegetation from a quantitative standpoint, the influence of the dominant taxa masks the presence or absence of the rarer ones and, in the case of the Cyanophyceae, a stabilization of the quantitative similarity coefficient occurs at a comparatively high value and at half the sampling area necessary to stabilize the qualitative similarity coefficient.

As described in the accompanying paper (Wilmotte \& Demoulin, 1988), while several taxa of Cyanophyceae regularly occur on Cladophora, more than half of the individuals belong to a single taxon. The uniform distribution of this taxon is 
TABLE II. Minimal sampling area $\left(\mathrm{mm}^{2}\right)$ and similarity values $(\%)$ reached at stabilization in various conditions

\begin{tabular}{|c|c|c|c|c|c|}
\hline & \multicolumn{3}{|c|}{ Minimal sampling area } & \multirow[b]{2}{*}{$\begin{array}{l}\text { Similarity } \\
\text { value } \\
\text { of } S_{t}\end{array}$} & \multirow[b]{2}{*}{$\begin{array}{l}\text { Similarity } \\
\text { value } \\
\text { of } S_{2}\end{array}$} \\
\hline & $\begin{array}{l}\text { Species/ } \\
\text { area } \\
\text { curve }\end{array}$ & $\begin{array}{l}\text { Qualitative } \\
\text { similarity } \\
\text { coefficient }\left(S_{1}\right)\end{array}$ & $\begin{array}{l}\text { Quantitative } \\
\text { similarity } \\
\text { coefficient }\left(S_{2}\right)\end{array}$ & & \\
\hline $\begin{array}{l}\text { Cyanophyceae on } \\
\text { Cladophora (Stareso, } \\
\text { July) } \\
\text { Cyanophyceae on } \\
\text { Cladophora (Ferry }\end{array}$ & $37 \cdot 5$ & 30 & 15 & 81 & 75 \\
\hline $\begin{array}{l}\text { Cladophora (Ferry } \\
\text { harbour, March) }\end{array}$ & $22 \cdot 5$ & - & - & - & - \\
\hline $\begin{array}{l}\text { Bangiophyceae on } \\
\text { Cladophora (Stareso, } \\
\text { July) }\end{array}$ & $7 \cdot 2$ & $7 \cdot 2$ & $9 \cdot 6$ & 94 & 66 \\
\hline $\begin{array}{l}\text { Bangiophyceae on } \\
\text { Halopteris }\end{array}$ & $0 \cdot 2$ & 0.2 & $0 \cdot 5$ & 100 & 80 \\
\hline
\end{tabular}

evidently important in stabilizing the quantitative similarity coefficient.

Such a phenomenon is not observed with the Bangiophyceae, for which there are less taxa of occasional occurrence, but where large variations in the abundance of some taxa seem possible.

Minimal sampling areas vary with the communities. One cannot, of course, ever be certain that the values determined in such a study can be extrapolated to other communities. They could even vary with the same type of community under different conditions that might effect either the epiphytes or the growth and physiology of the host. However, it seems that by choosing a value of 15 sampling units $\left(37.5 \mathrm{~mm}^{2}\right)$ for Cyanophyceae on Cladophora, one can obtain significant vegetation data, especially from a quantitative standpoint and thus approach the study of the influence of ecological conditions on epiphyte cover.

For Bangiophyceae on Cladophora we decided to use in our vegetation studies 20 sampling units $\left(24 \mathrm{~mm}^{2}\right)$. As with Cyanophyceae, the value chosen is about twice that determined with the quantitative similarity coefficient.

The Bangiophyceae on Halopteris seem a community more uniform and hence more easily described than that on Cladophora. The reason may lie in the fact that, given the different growth pattern, we can use here a rather well circumscribed part of the plant which might be of more uniform age than Cladophora shoots.

For Bangiophyceae on $H$. scoparia we used 30 sampling units $\left(3 \mathrm{~mm}^{2}\right)$. In this case, the minimum value determined is so low that one can take a much larger value without making observations prohibitively time consuming.

It should be noted that if one applies the criteria of Weinberg (1978)-who chooses as minimal sampling area the area for which a $80 \%$ qualitative similarity value is obtained, and $70 \%$ in case of a quantitative similarity, whether this corresponds to a stabilization of the curve or not-our minimal sampling areas remain unchanged or are even smaller.

One of the most encouraging aspects of this study lies in the values of the similarity coefficients obtained. Ranging from 81 to $100 \%$ for the qualitative and 66 to $80 \%$ for the quantitative, they compare well with those obtained in studies of macrophytic vegetation, whether terrestrial or submerged (Gounot, 1969; Boudouresque, 1974; Coppejans, 1977, 1980; Nedelec, 1979; Panayotidis \& Boudouresque, 1981).

If a satisfactory description of microepiphytic vegetation thus seems possible it should however be stressed that the minimal sampling areas that we have determined are high compared with areas that have been used in many studies of microepiphytes. For 
example, on the fresh-water C. glomerata, which is for our purpose morphologically comparable to C.prolifera, Sheath \& Morison (1982) use samples of 25 segments of branches of a length of $0.362 \mathrm{~mm}$, while we have used segments at least 16 times longer. While their dimension is usually unspecified, the samples used by authors describing epiphytes using the scanning electron microscope are very likely to be even smaller (Rosen, Kingston \& Lowe, 1981; Sieburth \& Tootle, 1981; Medlin, Fryxell \& Cox, 1985). Caution should thus be used in interpreting those reports, and more sampling studies of the type we have performed, with different basiphytes, in different habitats, should be welcomed.

\section{ACKNOWLEDGEMENTS}

Our field work has been performed at STARESO (Oceanographic Field Station of the University of Liège, in Calvi, Corsica) and we thank the Director, Professor A. Distèche, and staff for their cooperation. We also thank Dr J. P. Descy for his advice in mathematical vegetation study and Professor C. F. Boudouresque, Dr A. Breeman and Professor F. E. Round for their critical reading of the original manuscript. We are also grateful to $\mathbf{L}$. Smeets for his help in the underwater collecting and R. Gago for preparing the illustrations. During preparation of this paper A. Wilmotte was "Aspirant du Fonds National Belge de la Recherche Scientifique" whose support is also acknowledged in the framework for contract F.R.F.C. $24550-80$.

\section{REFERENCES}

Belsher, T. \& Boudouresque, C.-F. (1976). L'impact de la pollution sur la fraction algale des peuplements benthiques de Méditerranéc. In Atti Tav. rot. intern. "La Biologia marina per la difesa $e$ per la produttività del mare, Livorno 20-2I maggio 1974", 215-260. Stem-Mucchi, Modena.

Boudouresque, C. F. (1971). Méthodes d'étude qualitative et quantitative $\mathrm{du}$ benthos (en particulier du phytobenthos). Thétys, 3: 79-104.

Boudouresque, C. F. (1974). Aire minima et peuplements algaux marins. Soc. Phycol. France Bull., 19: 141-157.

Coppejans, E. (1977). Résultats d'une étude d'homogénéité de peuplements algaux photophiles sur substrat rocheux à Port-Cros et
Banyuls (France). Rapp. P.-v. Réun. Comm. int. Explor. scient. Mer méditerr., 24: 143-144.

Coppejans, E. (1980). Phytosociological Studies on Mediterranean Algal Vegetation: Rocky Surfaces of the Photophilic Infralittoral Zone. In The Shore Environment vol. 2: Ecosystems (Price. J. H., Irvine, D. E. G. \& Farnham, W. F., editors), 371-393. Academic Press, London.

Garbary, D. J., Hansen, G. I. \& SCaGel, R. F. (1980). The marine algae of British Columbia and Northern Washington. Division Rhodophyta (Red Algae), class Bangiophyceae. Syesis, 13: 137-195.

GeITLER, L. (1930-1932). Cyanophyceae (Blaualgen). In L. Rabenhorst's Kryptogamen-Flora, Bd. XIV. Akademische Verlagsges, Leipzig.

Golubić, S. (1970). Effect of Organic Pollution on Benthic Communities. Mar. Poll. Bull., N.S., 1: 56-57.

Goodall, D. W. (1973). Sample similarity and species correlation. In Ordination and Classification of Communities (Handbook of Vegetation Science V) (Whittaker, R. H., editor), 105-156. Junk, The Hague.

Gounot, M. (1969). Méthodes d'Étude Quantitative de la Végétation. Masson, Paris.

HoEk, C. VAN DEN (1963). Revision of the European Species of Cladophora. Brill, Leiden. Reprinted: Koeltz, Königstein (1976).

Kershaw, K. A. (1973). Quantitative and Dynamic Plant Ecology. Arnold, London.

Marcot-Coqueugniot, J., Boudouresque, C.-F. \& KNOEPFFLER, M. (1984,"1983"). Le phytobenthos de la frange infralittorale dans le port de Port-Vendres (Pyrénées-Orientales, France). Première partie. Vie milieu, 33: 161-169.

Medlin, L. K., Fryxell, G. A. \& Cox, E. R. (1985). Successional Sequences of Microbial Colonization on Three Species of Rhodophycean Macroalgae. Ann. Bot., 56: 399-413.

MundA, I. (1974). Changes and succession in the benthic algal associations of slightly polluted habitats. Rev. Int. Oceanogr. Med., 34: 37-52.

Nedelec, H. (1979). Etude Structurale et Problemes d'Échantillonnage dans une Phytocoenose Portuaire. Thesis for the Diplome d'Etudes Approfondies d'Océanographie Biologique, Université Pierre et Marie Curie (Paris VI).

Panayotidis, P. \& Boudouresque, Ch.-F. (1981). Végétation marine de l'île de Port-Cros (Parc National) XXI. Aire minimale et patchiness de la flore épiphyte des feuilles de Posidonia oceanica. Trav. sci. Parc. nation. Port-Cros, 7: 71-83.

Rosen, B. H., Kingston, J. C. \& Lowe, R. L. (1981). Observation of differential epiphytism on Cladophora glomerata and Bangia atropurpurea from Grand Traverse Bay, Lake Michigan. Micron, 12: 219-220.

Round, F. E. (1981). The Ecology of Algae. Cambridge University Press, Cambridge.

SChramm, W. \& Booth, W. (1981). Mass blooms of the Alga Cladophora prolifera in Bermuda. Productivity and Phosphorus Accumulation. Botanica mar., 24: 419-426.

SHEATH, R. G. \& Morison, M. O. (1982). Epiphytes on Cladophora glomerata in the Great Lakes and St 
Lawrence Seaway with particular reference to the red alga Chroodactylon ramosum (= Asterocystis smaragdina). J. Phycol., 18: 385-391.

Sieburth, J. Mc. N. \& Tootle, J. L. (1981). Seasonality of microbial fouling on Ascophyllum nodosum (L.) Lejol., Fucus vesiculosus L., Polysiphonia lanosa (L.) Tandy and Chondrus crispus Stackh. J. Phycol. 17: 57-64.

SøRENSEN, T. (1948). A method for establishing groups of equal amplitude in plant sociology based on similarity of species content. Biol. Skr. 5: 1-34.

WeinberG, S. (1978). The minimal area problem in invertebrate communities of Mediterranean rocky substrata. Mar. Biol., 49: 33-40.

Whitton, B. A. \& Potts, M. (1982). Marine littoral. In The Biology of Cyanobacteria (Carr, N. G. \& Whitton, B. A., editors), 515-542. Blackwell Scientific Publications, Oxford.

Wilmotte, A. \& Demoulin, V. (1988). Studies of marine epiphytic algae, Calvi, Corsica II: variations in the populations of epiphytic bluegreen algae in three harbours with different pollution loads. Br. phycol. J. 23: 259-266.

(Accepted 12 January 1988) 